\title{
Reification in Market Societies: Theoretical Conceptualizations and Researchability
}

\author{
EGIDIJUS MARDOSAS \\ Centre for Aristotelian Studies and Critical Theory, Mykolas Romeris University, 55 Didlaukio Street, 08303 Vilnius, Lithuania \\ Email: egidijus.mardosas@gmail.com
}

\author{
JOLITA VVEINHARDT, ALGIRDAS DAVIDAVIČIUS \\ Vytautas Magnus University, 58 K. Donelaičio Street, 44248 Kaunas, Lithuania \\ Email: jolita.vveinhardt@vdu.It; algirdas.davidavicius@vdu.It
}

\begin{abstract}
This article asks what philosophers can learn from social research in order to develop the notion of reification further. At first, we present a theoretical analysis of the concept of reification. Then we survey the main research into employment and management strategies through various sectors (industry, services and knowledge work) asking to what extent this research is informed by the notion of reification. The last part of the article focuses on Lithuanian research. We conclude that while the notion of reification is not often employed in contemporary social research, much of that research is close to the normative concerns implicit in the notion of reification. This research then provides a valuable input for further philosophical development of the theory of reification.
\end{abstract}

Keywords: reification, recognition, management, Critical Theory, social research

\section{INTRODUCTION}

In their critique of contemporary market societies, the philosophers of the Critical Theory tradition have developed the concept of reification. It was firstly developed in the early 20th century and recently - especially after the economic crisis of 2008 - it has been receiving growing attention in the contemporary debates on the power dynamics in workplaces. Various aspects of contemporary employment models and management practices are labelled as reifying: as negative phenomena that destroy the social and psychological wellbeing of the employees, dehumanize and disturb the workplace and diminish productivity. Alternative management models are proposed in order to create a more humane work environment and more sustainable and productive work relations.

However, the philosophical notion of reification aims to describe social reality - thus it is demanding empirical verification. It must be translated into empirically observable facts that could be researched by social scientists. This has been the original aim of the Critical Theory: 
to ground the critical analysis of the contemporary societies on the rigorous social-empirical research. In this article, we aim to analyse how successfully the notion of reification is employed for social research (with a special focus on the Lithuanian context) and how this research, in turn, can inform further theoretical development of the notion. With this article, we seek to contribute towards the greater dialogue between social philosophers and empirical researchers.

\section{THE NOTION OF REIFICATION IN CRITICAL SOCIAL PHILOSOPHY}

The first comprehensive theory of reification was provided by György Lukács in the early 20th century. His theory rests on the previous (mostly Karl Marx's) insights into alienation and commodification and it further develops the analysis of subjectivity in market societies. There exists an even earlier context: the analysis of modern subjectivity by the authors of the Enlightenment, especially John Locke and Jean-Jacques Rousseau. But Lukács was the first to clearly highlight and explain the modern phenomenon of reified subjectivity and to conceive it as the fundamental and general aspect of contemporary market societies.

Lukács argues that in market societies, much more than in pre-modern ones, all subjectivity is subsumed under certain rationalistic logic aiming to decompose human experiences and even human personality into components that could be accounted, controlled and valued in economic terms; components that either have market-exchange value or do not. According to Lukács, because workers are forced by the structural conditions of market societies to sell their labour, they themselves acquire the qualities of commodity, they become thing-like. Workers are separated from their previous pre-economic context of existence and lose all other independent and non-economic significance: their non-economic social value as persons, their moral autonomy. To use the language of contemporary management, they become an instance of 'human resources'.

As resources, human beings lose their authenticity, spontaneity and autonomy and become subordinated to the needs and the will of employers and managers. Such transfer of the autonomy and the ethical sovereignty to control and decisions of others is possible because of the two-directional relations of reification. On the one hand, the active side of work relations (i.e. employers) reifies at least a part of the personal features of the employed by prescribing them an economic value and, as owners of the means of production, by directly controlling them. 'Human resources' become just another part of the resources of economic activity that are disposed of by those who 'own' them. The common discursive cliché 'we have invested in you' attests to such relation. On the other hand, there must be certain self-reification - successful labour market could not function if the people who seek employment did not perceive themselves as a set of objectified features that have a market value and could be 'sold'. In addition, the reification of the other and of oneself is always discriminatory: all personal features that have no economic value lose any objective significance. According to Lukács:

'[reification] stamps its imprint upon the whole consciousness of man; his qualities and abilities are no longer an organic part of his personality, they are things which he can "own" or “dispose of" like the various objects of external world” (Lukács 1971: 100).

Lukács conceives reification as all-encompassing and concludes that the objectification and commodification of persons and all physical, social and mental reality have become the dominating form of rational understanding of the real: the main socio-economic category in market societies (ibid. 86). This does not mean that reification was absent in pre-market 
societies, but, in Lukács' view, the modern reification touches every person as long as she takes part in any activity that has an economic dimension. Furthermore, in market societies the reification becomes universal without the use of violence; it is sustained by 'free' contract (Pateman 2002; Coleman 2005).

But why, following Lukács, reifying relations become so total? What anthropological assumption allows us to treat each other to a certain extent as things? How is this assumption institutionalized? To provide an answer, later authors point to the principles of private property as spelt out by John Locke (McPherson 1978; Pateman 2002; Coleman 2005; Honneth 2008). To Locke, the basic principle of private property - the foundation of market societies - is control of objects through 'labour' as management and alteration of their parameters (Locke 1988: 305-306). Property control creates objectification: anything that is available for purposeful activity (labour) is turned into an object of control. This relation reifies that part of reality that can be controlled and altered, including the human body, psyche and experiences. Property relations for Locke also include property in self - i.e. only atomised and autonomous individuals who treat their selves as property can enter into free contractual relations of exchange, including the exchange of their own labour.

C. B. Macpherson labelled this modern proprietary understanding of the self as 'possessive individualism' (Macpherson 1978: 263-264). According to him, it creates two socio-pathological outcomes. First, possessive individuals lack ethical obligations to altruism or solidarity; they are already in the position of moral egotism. Second, it causes emotional blindness to the needs of others, raises emphatic barriers or distances. Such individualism treats persons as sets of separable and economically valuable features: work hours, personal talents, efforts, services, even body parts (see Pateman 2002: 23-36). According to D. Ellerman, the essence of wage-contract between Lockean possessive individuals is human rentals: the use of one person's abilities for the profit of another. Structurally it is not different from the rental of the material equipment, because it implies the subordination of one's reified integral parts (part of one's time, talents, intellectual and manual activities) to the will and control of the other. Even in the best of wage-relations the 'rented' persons are to a certain extent dehumanized and stripped of their ethical and psychological autonomy (Ellerman 1993).

Such possessive social relation is hardly compatible with ethical relations of emotional resonance, empathy and compassion. A. Honneth develops the theory of reification further by interpreting it in the light of his theory of recognition that describes interpersonal relations that sustain moral and intellectual development. In such relations, the desires and abilities of other persons are recognized as socially valid and are allowed to flourish not only interpersonally but also institutionally. Reification in his theory is defined as forgetfulness of recognition, certain interpersonal and social blindness (Honneth 2008). But Honneth recognizes that reification is almost unavoidable in contemporary societies. Reification as pathological emotional and ethical blindness is only a distortion of otherwise rational, objectifying modern relation with oneself, with others and with reality or its imbalance with the needs of solidarity and empathy.

At the same time, the ever-increasing division of labour in contemporary societies creates, according to Honneth, ever more space for individuals to seek the realization of their personal talents and abilities (Honneth 2007). But, if market societies and their institutions embraced more principled positions of interpersonal and intercultural recognition, then the harmful aspects of reification - dehumanization, exploitation, abuse and other aspects of violent and controlling relations - would be mitigated and would not threaten economic and 
democratic legitimacy. Honneth stresses that current practices of employment should seek to embrace and sustain the ethical standards of recognition.

To conclude, reification is understood as the loss of personal autonomy and integrity arising from the norms of possessive individualism. It creates harmful, pathological outcomes by allowing (but not necessarily commanding) dehumanizing and exploitative relations of control. The more such relations establish and spread, the more there is a need for solidarity and ethical recognition among individuals, groups and organizations. By the theory of reification, to be sustainable must be grounded on sociological research. Reification must not be only reflected philosophically, but also empirically revealed in various economic sectors. Our next step is to inquire to what extent the notion of reification is 'translatable' to social research.

\section{REIFICATION IN MANAGEMENT THEORY}

Before turning to social research proper, it is important to look at the management theory: does the notion of reification inform the theoretical reflection on the organization of work and managerial practices? Contrary to social philosophy, the term 'reification' in management theory is rarely used. However, G. Islam showed that it is easy to connect the theory of reification with contemporary management theory (Islam 2013). According to Islam, Honneth's understanding of reification can be applied as a normative ground for management theory. Reification in the workplace can be described as misrecognition or forgetfulness, as a mistake in interpersonal relations, when the employer or direct manager, occupying the position of power, fails to recognize employee as reasoning, desiring subject with the need for personal wellbeing.

Islam provides many examples of reifying practices that cause the instrumentalization, dehumanisation and de-contextualisation of the employees and their work. For example, when the manager is motivating his subordinates only with material gain (higher salary) without paying attention to other significant factors of the well-being of the workers, such as the general psychological atmosphere in the workplace or the opportunities to balance work with personal life. Reification is also evident when the employee is treated as a set of features that are useful for the company, and not as an autonomous person. His talents and capabilities are seen as separate from his overall personality. By using Honneth's theory, Islam can criticise actual reifying practices without denying the possibility for the relation of recognition in contemporary capitalist societies. This allows Islam to raise the question of ethical management that would place the care and recognition of the other at the centre of managerial practices.

A similar normative orientation can be seen in J. Hoogervorst's critique of the theories of organization (Hoogervorst 2018). He focuses on notions and practices that reduce the employee to a human resource - according to Hoogervorst such instrumental reasoning leads to exploitation, alienation and dehumanization (ibid. 133). Hoogervorst highlights various situations when workers are instrumentalised. He points to bureaucratic and hierarchical relations that aim at a clear separation of work, functional differentiation, depersonalized relations and formal communication, enforcement of discipline and hierarchical control (ibid. 118). All these lead to negative outcomes and must be opposed by what Hoogervorst calls 'employee-centric theory of organization' that treats employees as autonomous persons and understands that companies have moral obligations for the well-being of the wider community.

Some authors remain sceptical as to whether ethical management under contemporary neoliberal capitalism could be possible at all. M. Greenwood (2002) provides a survey of human resources management $(\mathrm{HR})$ theory as it developed from the mainstream standpoint that 
takes it as a neutral strategy to increase the efficiency and productivity of a firm, to the critical standpoint that rejects HR as a tool of manipulation and exploitation, to the 'ethical school' that seeks to give it a normative grounding by applying various ethical philosophies (deontology, utilitarianism or others). But, according to Greenwood, the critical analysis of management practices done by the 'ethical school' only highlights that even the minimal moral standards - the respect of human dignity and individual freedom - remain alien to actual HR practices under neoliberalism. Greenwood's analysis points to the conclusion that human resource management itself belongs to the reifying tendencies of contemporary socio-economic order by actively supporting or simply failing to break through the instrumentalist and profit-oriented practices imposed by the competition in the neoliberal market.

\section{SOCIOLOGICAL RESEARCH INTO REIFYING WORKPLACE PRACTICES}

The theory of reification inspired important research aiming to reveal how reification manifests in concrete work environments. The first fundamental works were done by M. Burawoy who developed and employed the method of direct ethnographic observation. He aimed to observe social, economic and cultural practices in different workplaces and to collect data from different geographic regions. Burawoy developed his method in the 1970s by hiring out as a worker in factories and other firms in the USA, Zambia and later in communist Hungary and post-soviet Russia. His research revealed concrete dynamics between different power positions in different workplaces (Burawoy 1985). In our view, he has successfully operationalised Lukács' theory by creating critical sociology that describes the social reality of unequal power positions in such a way as to reveal the process of reification as concrete socio-economic practices.

P. Thompson and D. van den Broek (2010) show how Burawoy's research created the debate about 'workplace regimes and management control'. Burawoy-inspired research aimed to reveal how managerial hierarchy and discipline is sustained in concrete workplaces and to highlight the dynamics of domination and resistance. The first wave of research focused on large industrial enterprises (ibid. 4). Later the research was expanded to study other sectors, especially services. This was motivated by the structural changes in the global economy: with globalization and neoliberalism, deindustrialization started in the West and the service sector experienced unprecedented growth. New research focused on emotional work. A classical study in his field remains A. R. Hochschild's The Managed Heart: Commercialisation of Human Feeling (2012) that developed the notion of emotional labour. Although Hochschild was not using the term 'reification', her account of estrangement from personal feelings illustrates the concept well. Reification of emotional states becomes more and more widespread with the further growth of the service sector - forced smiles and politeness and even obligatory intimacy between co-workers (see, for example, P. Mason's account of how in some enterprises the workers are encouraged to touch each other; Mason 2016: 208).

S. Ekman (2012) surveyed workplace dynamics in knowledge work, thus providing a significant contribution next to the studies of industrial workplaces and service sector. Ekman used direct ethnographic observation and repeated interviews in order to reveal competing views about work and workplace relations between managers and employees. She recognized two types of discourse: authenticity and contractuality. Authenticity discourse sees work as a creative activity, with the desire for self-realization and the expectations of continuous personal growth. Contractuality accentuates limits, standards, observation of rules and pragmatism (ibid. 82). 
As far as reifying ideas and practices are concerned, they are best revealed in the views of managers using 'contractuality' discourse. Ekman observes that managers who perceive the workplace only in terms of instrumentality and hierarchy often use phrases such as 'being realistic, 'adjusting to the reality', and they tend to understand their work as curbing the unrealistic hopes of their subordinates (ibid. 173). Ekman's research reveals that the workers who 'speak the language of authenticity' are offended by managerial formalities and rules (ibid. 171). Instrumental managers even expect that they will leave employees dissatisfied, especially those who seek authenticity. Thus, the conflict between the ideals of employees and instrumental managerial goals for them are natural part of the workplace dynamic.

Ekman's research illustrates the wider contemporary discussion about work: hierarchical, instrumental relation is no longer acceptable for many workers. Some authors claim that such managerial practices must be ditched immediately. For example, P. Mason argues that the only reason dehumanizing workplace practices persist is that neoliberal competition forces companies to increase exploitation. Many contemporary managers reject the ideals of productive and personally fulfilling work; an ideal that, according to Mason, dominated in the early 20th century (Mason 2016: 288).

\section{RESEARCH OF WORKPLACE RELATIONS IN LITHUANIA}

Looking at the conceptual apparatus used in labour sociology in Lithuania, the notion of turning into a thing (reification) is not altogether alien. For example, A. Kiaunyte and D. Puidokiene (2011) draw an opposition between the relation that turns the other into a thing and the dialogical interpersonal relation. But in their research, it is applied only to the interactions between a service provider and a customer and is not applied to analyse the dynamics inside the workplace.

M. P. Bal and E. Dóci (2018) argue that instrumental managerial relation is a general feature of the neoliberal economy. Thus, it is reasonable to expect that such relation is as widespread in Lithuania as in any other neoliberal country. As G. J. Neimanis (1997) observed, the transition from the planned command economy to market economy demands that social and economic environment where everyone follows the rules, and no one is responsible, should be dismantled. The lack of personal responsibility does not encourage ethical behaviour in any part of life (ibid. 357). On the other hand, for many years in Lithuania the priority was given to develop a liberal market as the means to catch up with the more economically advanced countries. Societal wellbeing has been understood as the natural outcome of the market. In this context human resource paradigm was treated positively as the effective means to reach higher productivity and competitiveness (Česynienè 2005; Stasiulytė 2011; Čižiūnienè et al. 2016); productivity and competitiveness would, in turn, bring well-being. It is observed that the process of neo-liberalization was much more intense in Lithuania than in other post-communist countries (Norkus 2008).

The doctrine of corporate social responsibility is sometimes seen as a way to respond to the process of employee dehumanization and to instil respect for personal dignity (Martin 2015). But the research done in Lithuania reveals that corporate social responsibility faces serious difficulties. For example, R. Kazlauskaitė and I. Bučiūnienè (2010: 2018) have shown that almost half of all companies had instituted some policies of social responsibility, but only a few of them took action that was not prescribed by law. Other research (Vveinhardt et al. 2018) has shown that companies, that declared social responsibility, in reality have a poor record of dealing with psychological violence in the workplace, with managers lacking empathy and exercising their functions from the position of power. 
A survey of Lithuanian companies revealed that technocratic control and the 'hard' model of human resource management dominate; the model emphasises control, maximum exploitation of the potential of employees and seeks maximum gain without attention to the needs of employees (Česyniene 2005: 54). The author observes that the inclusion of workers into company management structures, which is practised in some countries, is virtually non-existent in Lithuania. A. Davidavičius observes high stress levels among Lithuanian workers and points out that instrumental understanding of the employees is one of the reasons, also admitting that there is a lack of research into relations in the workplace (Davidavičius 2009). Research into the tendencies of value congruence of organization and employees revealed lack of competence among supervisors and inadequate recognition of the values of employees (Vveinhardt et al. 2016: 261). The long-term analysis of change in values of Lithuanian society during the last two decades (Žiliukaite et al. 2016) revealed that work itself is progressively less valued in relation to other aspects of life and, secondly, that what is perceived as valuable and important in work also changes. But the dominant ideological agenda does not allow adequately addressing the changing needs and values of the employees.

This short survey does not allow making broad conclusions, but it indicates that there exist features in the current business environment that point to the phenomenon of reification. But there remains a lack of research of concrete reifying practices and discourses in Lithuanian workplaces.

\section{CONCLUSIONS}

The philosophical notion of reification historically was subject to reinterpretation and reformulation: from Lukács's anti-capitalist perspective to Honneth's vision of division of labour that respects human individuality and dignity. Honneth's conceptualisation is more readily embraced by social researchers.

Our analysis of contemporary social research into workplace practices and managerial theory showed that few researchers use the term reification and acknowledge its philosophical background. But we have observed that social researchers' concern with more humane workplace dynamics share a normative orientation that is close to the concerns of the theory of reification.

The survey of social research revealed that the notion of reification can be successfully applied to study various sectors: industry, services and knowledge work. The scope of the existing research provides an important argument for the vitality of the philosophical theory of reification.

The research of labour relations in Lithuania points to possible high levels of reification, but there remains a lack of research into power dynamics and practices in concrete workplaces that would allow addressing the question of reification more comprehensively.

Received 19 September 2019

Accepted 20 November 2020

\section{References}

1. Bal, M. P.; Dóci, E. 2018. 'Neoliberal Ideology in Work and Organizational Psychology', European Journal of Work and Organizational Psychology 27(5): 536-548.

2. Burawoy, M. 1985. The Politics of Production: Factory Regimes Under Capitalism and Socialism. London: Verso.

3. Coleman, J. 2005. 'Pre-Modern Property and Self-ownership Before and After Locke: Or, When did Common Decency Become a Private Rather Than a Public Virtue?', European Journal of Political Theory 4(2): 125-145. 
4. Česynienè, R. 2005. 'The Most Recent Trends and Emerging Values in Human Resource Management: Comparative Analysis', Engineering Economics 4(44): 50-55.

5. Čižiūnienè, K.; Vaičiūte, K.; Batarlienè, N. 2016. 'Research on Competencies of Human Resources in Transport Sector: Lithuanian Case Study', Procedia Engineering 134: 336-343. DOI: 10.1016/j.proeng.2016.01.016.

6. Davidavičius, A. 2009. „Kodèl mes taip prastai jaučiamès dirbdami ir ar galime jaustis geriau?", iš Bielskis, A. (sud.) Demokratija be darbo judèjimo? Kaunas: Kitos knygos, 184 p.

7. Ekman, S. 2012. Authority and Autonomy: Paradoxes in Modern Knowledge Work. New York: Palgrave Macmillan.

8. Ellerman, D. 1993. Property and Contract in Economics: The Case for Economic Democracy. New York: Blackwell.

9. Greenwood, M. 2002. 'Ethics and HRM: A Review and Conceptual Analysis', Journal of Business Ethics 36(3): 261-278.

10. Hochschild, A. R. 2012. The Managed Heart: Commercialization of Human Feeling. Berkely, Los Angeles, London: University of California Press.

11. Honneth, A. 2007. 'The Social Dynamics of Disrespect: On the Location of Critical Theory Today', in Disrespect: The Normative Foundations of Critical Theory, ed. A. Honneth. Cambridge, Malden: Polity, 63-79.

12. Honneth, A. 2008. 'Reification and Recognition: A New Look at an Old Idea', in Reification: A New Look at an Old Idea, ed. M. Jay. Oxford: Oxford University Press, 17-96.

13. Hoogervorst, J. A. P. 2018. Practicing Enterprise Governance and Enterprise Engineering: Applying the EmployeeCentric Theory of Organization. New York: Springer.

14. Islam, G. 2013. 'Recognizing Employees: Reification, Dignity and Promoting Care in Management', Cross Cultural Management 20(2): 235-250.

15. Kazlauskaite, R.; Bučiūnienè, I. 2010. 'HR Function Developments in Lithuania', Baltic Journal of Management 5(2): 218-241. Available at: https://doi.org/10.1108/17465261011045133

16. Kiaunyte, A.; Puidokienè, D. 2011. „Dialogas kaip ugdomasis susitikimas socialinio darbo kontekste“, Acta Peadagogica Vilnensia 27: 124-138.

17. Locke, J. 1988. Two Treatises of Government. New York: Cambridge University Press.

18. Lukács, G. 1971. 'Reification and the Consciousness of the Proletariat', in History and Class Consciousness, ed. G. Lukács. Cambridge: MIT Press, 83-222.

19. Macpherson, C. B. 1978. The Political Theory of Possessive Individualism: from Hobbes to Locke. Oxford, New York: Oxford University Press.

20. Martin, I. 2015. 'Corporate Social Responsibility as Work Law? A Critical Assessment in the Light of the Principle of Human Dignity', Canadian Labour and Employment Law Journal 19(1): 1-25.

21. Mason, P. 2016. Postcapitalism: A Guide to Our Future. London: Penguin.

22. Neimanis, G. J. 1997. 'Business Ethics in the Former Soviet Union: A Report', Journal of Business Ethics 16(3): 357-362. Available at: https://doi.org/10.1023/A:1017976419107

23. Norkus, Z. 2008. Kokia demokratija, koks kapitalizmas? Vilnius: Vilniaus universiteto leidykla, 744 p.

24. Pateman, C. 2002. 'Self Ownership and the Property in the Person: Democratization and a Tale of Two Concepts', The Journal of Political Philosophy 10(1): 20-53.

25. Thompson, P.; van den Broek, D. 2010. 'Managerial Control and Workplace Regimes: An Introduction', Work, Employment \& Society 24(3): 1-12.

26. Stasiulyte, E. 2011. 'Motives of Human Resource Management Outsourcing: A Case Study from Lithuania, Economics \& Sociology 4(1): 115-124. DOI: 10.14254/2071-789X.2011/4-1/11.

27. Vveinhardt, J.; Andriukaitiene, R.; Vienazindiene, M. 2018. 'Harassment and Bullying from the Prospect of CSR: Impact on the Welfare Perceived by Employees', Transformations in Business \& Economics 17(2): 66-85.

28. Vveinhardt, J.; Gulbovaite, E.; Streimikiene, D. 2016. 'Values Congruence from the Executives' Viewpoint: Value-based Practices', Economics \& Sociology 9(2): 248-265. DOI: 10.14254/2071-789X.2016/9-2/17.

29. Žiliukaitė, R.; Poviliūnas, A.; Savicka, A. 2016. Lietuvos visuomenès vertybių kaita per dvidešimt nepriklausomybés metu. Vilnius: Vilniaus universiteto leidykla, $316 \mathrm{p}$. 
EGIDIJUS MARDOSAS, JOLITA VVEINHARDT, ALGIRDAS DAVIDAVIČIUS

\title{
Reifikacija rinkos visuomenèse: teorinè samprata ir ištirtumas
}

\begin{abstract}
Santrauka
Straipsnyje keliamas klausimas, ką filosofija gali išmokti iš socialinių tyrimų, kai siekiama toliau plètoti reifikacijos sampratą. Pirmojoje straipsnio dalyje pristatoma teorinè reifikacijos sampratos analizė. Toliau aptariami darbuotojų samdos ir vadybos strategijų ìvairiuose sektoriuose (pramonès, paslaugų, žiniomis grịsto darbo) tyrimai, dėmesys kreipiamas $\mathfrak{i}$ tai, kiek šiuose tyrimuose atsiskleidžia reifikacijos samprata. Paskutinèje dalyje gvildenami Lietuvoje atlikti tyrimai. Daroma išvada, kad socialiniuose tyrimuose reifikacijos terminas nèra dažnas, tačiau analizuotuose tyrimuose iškeliamos problemos yra artimos reifikacijos sampratos normatyviniams orientyrams. Aptarti tyrimai suteikia reikšmingos medžiagos toliau filosofiškai plètoti reifikacijos sampratą.
\end{abstract}

Raktažodžiai: reifikacija, pripažinimas, vadyba, kritinė teorija, socialiniai tyrimai 